\title{
Architectural Design Evolution of the Malay Traditional Houses Along Sungai Perak
}

\author{
Sabrizaa Rashid*a ${ }^{*}$ Kartina Alauddin ${ }^{\mathrm{b}}$,Mohd Nurfaisal Baharuddin ${ }^{\mathrm{c}}$,Iryani \\ Abdul Halim Choo ${ }^{\mathrm{d}}$ \\ ${ }^{\mathrm{a}, \mathrm{b}, \mathrm{c}, \mathrm{d}}$ Center for Knowledge \& Understanding of Tropical Architecture \& Interior \\ (KUTAI), \\ Faculty of Architecture, Planning \& Surveying \\ Universiti Teknologi MARA (UiTM Cawangan Perak), \\ 32610 Seri Iskandar, Perak. \\ *Corresponding Author: mohds637@perak.uitm.edu.my
}

\begin{abstract}
Sungai Perak is the second longest river system in Peninsular Malaysia flowing along $400 \mathrm{~km}$ of river basin. For hundreds of years Sungai Perak has been the seat of the traditional Malays of Perak. Used as the main 'highway' during its heyday, it is seen as the economic, social and political seat of the Perak royals. Sungai Perak also forms the heart of the transportation and communication for the people of Perak. As with other main rivers systems Sungai Perak holds many wealth and secrets. Remnants of old Malay palaces, traditional houses, royal tombs and vernacular mosques can be seen to this day along the river basin, as prove of the existence of the old Malay civilization. Architecturally, traditional house was built not only for shelter and safety reasons. All forms of traditional architecture are built to meet specific needs, accommodating the religious, cultural values and way of life. Based on these circumstances, it tends to evolve over time to reflect the environmental, cultural, technological and historical context in which it exists. However, this traditional Malay home will face extinction if it is not well preserved and documented for future reference. This paper discusses the development of architectural style on the Malay houses at Sungai Perak. Fifty (50) houses in Kampung Aji, Bota Kiri were documented and analyzed chronologically. The evidence is derived from sixty houses as case study. Data is collected through site observation and variety sources of documentation. The roof design, spatial organization and architectural elements several types of architectural design were found in the period of 150 years. All of these shapes up the evolution of architectural design of the Malay houses in Perak and contribute as an extension of knowledge to the traditional Malay architecture in Malaysia.
\end{abstract}

Keywords: Heritage, Malay Architecture, Sungai Perak, Traditional Malay House

\section{Introduction}

Geographically Sungai Perak flows along approximately 400km from the mountainous North Eastern part of the state of Perak or Hulu Perak until a place called Beting Beras Basah in Bagan Datuk before meeting the Straits of Malacca. Sungai Perak is the second longest river system in Peninsular Malaysia after Sungai Pahang. Along 
the river there are traditional Malay villages, vernacular houses, mosques, old fort and royal tombs that hold many mysteries on its long socio-cultural and economic history of the traditional Perak Malays. Traditional villages along the banks of Sungai Perak across the State of Perak are considered one of the areas that are still remaining the Perak Malay identity. The history of the Malay Sultanate of Perak presents the civilization and cultures which may be storing history. Sungai Perak confluence was in Lumut through Sungai Dinding which is now one of the tributaries at Kubang Aji.

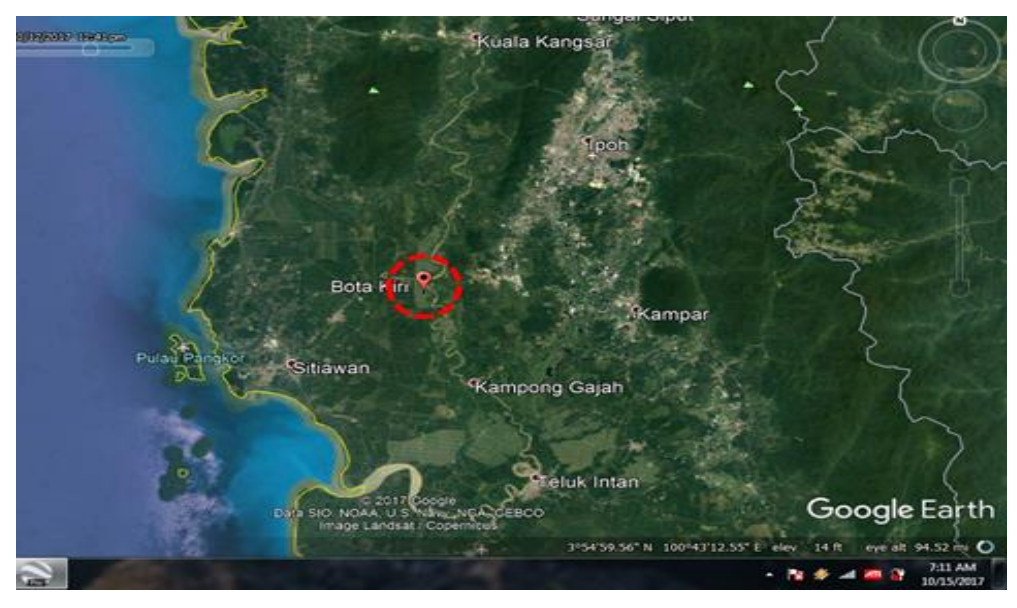

Figure 1. The location of Kampung Aji, Bota Kiri

The aim of this paper is to discuss the development of architectural style on the Malay houses along Sungai Perak. Towards attaining this aim, a qualitative research approach is used to achieve the two objectives. First, literature review is used to determine the Traditional Malay Houses as Perak architectural heritage. Second, sixty traditional houses along Sungai Perak are presented and analysed to discusses the development of architectural style on the Malay houses. Finally, research conclusion attach with the list of chronology of 60 houses in Kampung Aji, Bota, Perak.

\section{Traditional Malay Houses as Perak Architectural Heritage}

The design and style of traditional architecture is derived from several factors such as environmental factors (i.e. response to climate and weather), socio-cultural factors and beliefs and religions. With the exception of hypothetical, climate in Malaysia classified as humid heat that characterizes a relatively high temperature, rains throughout the year and has a high humidity level. Apart from that, Malay culture and Islamic religion as the faith and practice of the Malay population affects the formation of style traditional Malay house architecture.

Sabrizaa (2017) when discussing about architecture along Sungai Perak has stated in his book title "Rumah Kutai : Documentation of Memories" that basically Perak's architecture can be divided into three categories:
i. Traditional Malay architecture
ii. Colonial architecture
iii. Modern architecture 
The traditional Malay architecture found along the riverbanks of Sungai Perak is mostly in the form of old Malay palaces, traditional houses and mosques. Apart from major towns, Colonial architecture are mostly located in several towns along Sungai Perak such as Kuala Kangsar, Manong, Parit, Bota, Pasir Salak, Kampung Gajah and Teluk Intan where many houses, schools, offices, rest houses, mosques and hospital still stands and in use to this day. The Modern architecture mostly was built in new era or post-independent era

A typological study of the traditional architecture established at least two main categories or architectural styles namely:

i. $\quad$ Rumah Kutai (RK)

ii. Rumah Limas Bumbung Perak (RLBP)

\section{Rumah Kutai (RK)}

Rumah Kutai is the residential architectural design which was built, before the 1900. In Perak, "kutai" means old or ancient. From the architectural perspective, Rumah Kutai can be refers as traditional Perak Malay house in which the house is defined by Rumah Ibu (the main house) using Bumbung Panjang (long roof) or Bumbung Melayu (Malay roof) criteria. Table 1 shows the summary of characteristics of Rumah Kutai from previous studies including from Gibbs (1987), Lim (1987), Halim Nasir (1988), Halim Nasir and Wan Hashim (1996), Anuar Talib (2004), Norhasandi (2010), Sabrizaa Rashid (2008-2017).

Table 1: The characteristics of Rumah Kutai.

\begin{tabular}{|c|c|c|c|c|c|}
\hline Categories & Basic Design & $\begin{array}{c}\text { Architectural } \\
\text { Elements }\end{array}$ & Opening & $\begin{array}{c}\text { The } \\
\text { Ground }\end{array}$ & $\begin{array}{c}\text { The Sense of } \\
\text { Aesthetic }\end{array}$ \\
\hline $\begin{array}{l}\text { - Rumah Kutai } \\
\text { Asli } \\
\text { - Rumah Kutai } \\
\text { Beranjung } \\
\text { - Rumah Kutai } \\
\text { Anjung Beranda }\end{array}$ & $\begin{array}{l}\text { - Rumah Ibu (The } \\
\text { main house) } \\
\text { - Rumah Anjung } \\
\text { (The front } \\
\text { house) } \\
\text { - Rumah Tengah } \\
\text { or } \quad \text { Rumah } \\
\text { Selang (The } \\
\text { middle house) } \\
\text { - Rumah Dapur } \\
\text { (The kitchen } \\
\text { annex) }\end{array}$ & $\begin{array}{l}\text { - Roof } \\
\text { - Roof Structure } \\
\text { - Wall }\end{array}$ & $\begin{array}{l}\text { - Windows } \\
\text { - Doors } \\
\text { - Floors }\end{array}$ & - Stilts & $\begin{array}{l}\text { - Tebar layar } \\
\text { - Lebah } \\
\text { bergantung } \\
\text { - Selak } \\
\text { Cantik/Alas } \\
\text { Bendul } \\
\text { - Lubang angin } \\
\text { - Kepala pintu and } \\
\text { tingkap }\end{array}$ \\
\hline
\end{tabular}

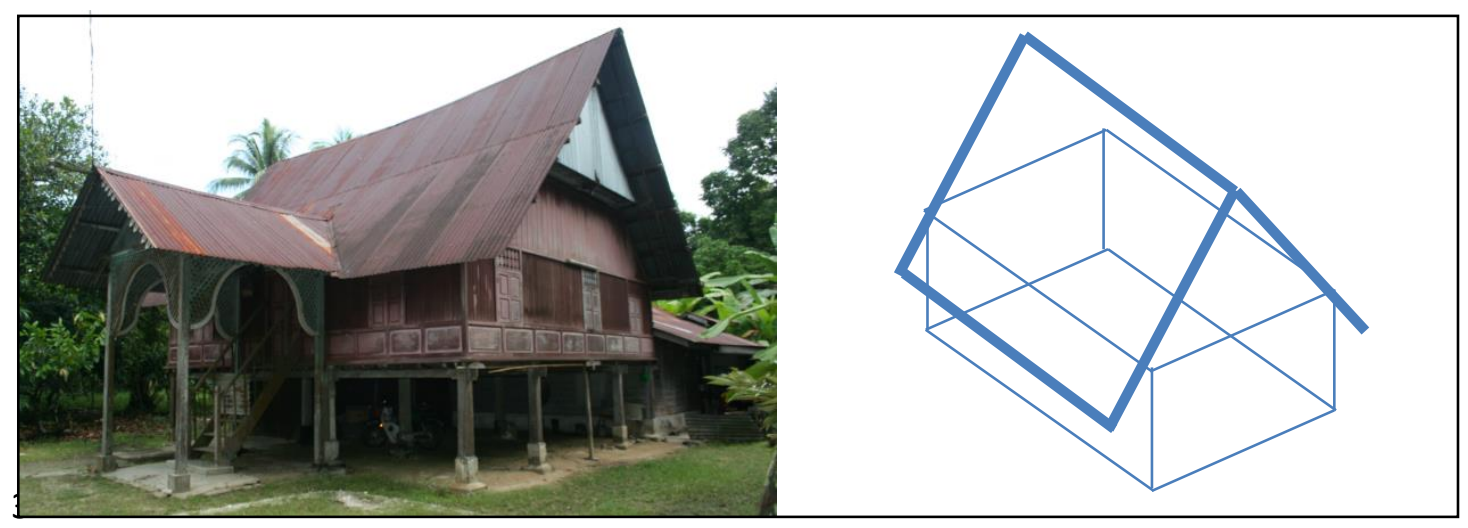


Figure 1: Rumah Kutai (RK) (source : Author)

Rumah Kutai design carries in it the features and characteristics of the Malay itself. Rumah Kutai is modest with flexible interior space and usage as well as able to blend well with the environment. Rumah Ibu is the main part of the building. It shows the significant emphasis by the builder as well as the house owner from the aspects of design, material selection and construction technology. For Rumah Kutai Asli, rumah ibu has the main area such as serambi luar and serambi dalam, ruang tengah, bedroom and main stairs. Rumah anjung has raised floors which are suitable as it hosts many important formal events such as merisik, solemnization ceremony, wedding reception and religious activities. Rumah tengah has a second stairs which is usually used by the ladies. Rumah dapur is for female guests assists the host in some formal and informal events. Rumah dapur is located at the back of the house and has the third staircase. In terms of architectural elements, roof tiles and roof structures are considered an important element for Rumah Kutai since it protects the house from climatic pressures. The roof shape has durability, aesthetics, comfort and the ability to withstand climatic changes. All Rumah Kutai's wall can be divided into three types of wall, Tepas (split and woven bamboo) or bertam (woven bark from Bertam tree); Tepas or bertam with wooden planks.

\section{Rumah Limas Potong Perak (RLBP)}

The architectural styles unique to Perak can be traced back to the 19th century where most buildings feature the style Bumbung Potong Perak or Potong Belanda. It is also called Rumah Limas Bumbung Perak and incorporates several decorative elements such as the Tunjuk Langit, Kepala Cicak, Papan Cantik, Kepala Tingkap, Kepala Pintu which gives its unique quality. The spatial design of the house also consists of rumah Ibu (main living room), rumah anjung, rumah selang and rumah dapur (kitchen) together with intermediary spaces such as anjung, serambi, ruang tengah and ruang dapur form a comprehensive architectural vocabulary that represent the traditional architecture of the Perak Malays.

The design of roof of rumah limas potong perak or bumbung perak or rumah potong belanda began to be known in the early 20th century. It was believed that it is imitation the Dutch style during the colonial era. The usage of zinc as a roofing material had contributed to changing in roof design of rumah limas. The design of roof of rumah limas potong perak is well known on the west coast of the peninsula of Malaysia. The 
origin of the word limas is difficult to determine. However, according to craftman Tuan Haji Muhamad bin Ismail in Lenggong, Perak, the word limas comes from the word "five" because the roof of this house type usually has five ridges (Halim Nasir (1996). The construction of rumah limas considered different from rumah kutai. Rumah limas used nail concept to strengthen all the structure. Rumah limas construction apparently easier to construct compare to rumah kutai, it is can be built by Chinese craftsmen. As examples, rumah limas added with new and modern are the addition of garage spaces, stone or concrete kitchen spaces located below (on land), modern bathrooms etc.

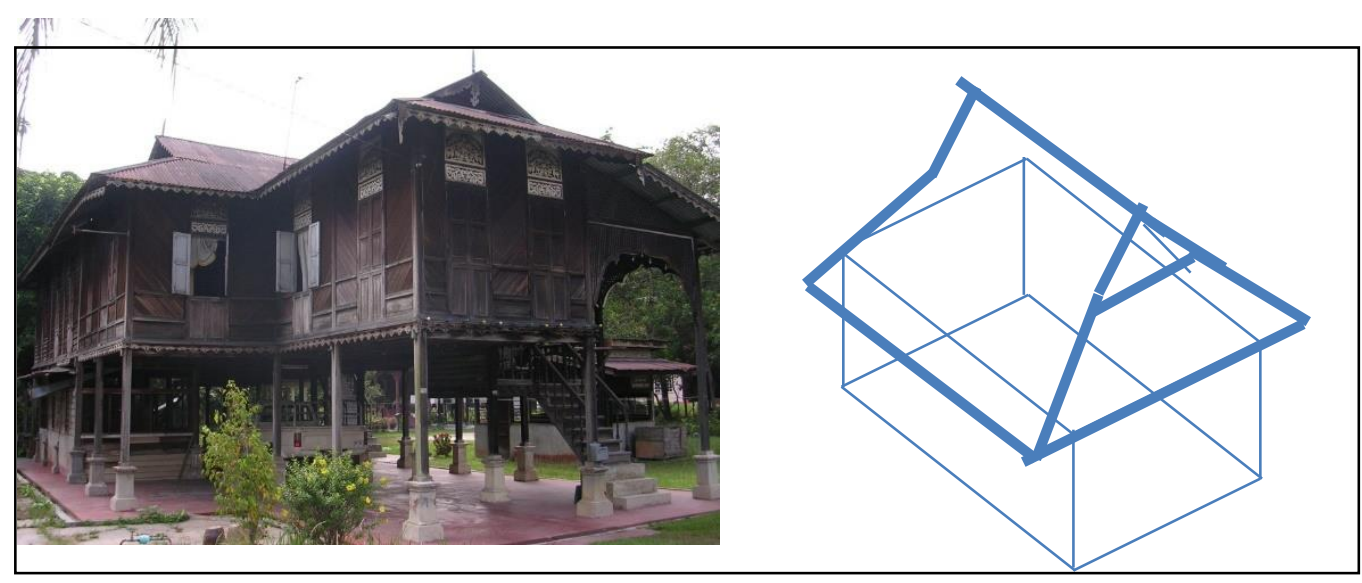

Figure 2: Rumah Limas Bumbung Perak (RLBP) source : Author

\section{Research Methodology}

\section{Data Collection}

The method used for this study is exploratory research and Oral History Research Method. Visual data and verbal data were taken through site observation. This method of conducting research at the site with the researcher feels the atmosphere and environment of the subject as well as interviews with the population / users in order to obtain more accurate and valid primary data.

Case Study. Kampung Aji, Bota Kiri, Bota is selected as case study for this research. The justification of the case study selection are Kampung Aji located in area that easy to access from the main road, the sample population (50 to 60 houses) are suitable for the sample size and the houses in this area consists of various architectural forms. The area parameter is between Sultan Idris Shah II bridge on the east and JPS water pump house on the west; Sungai Perak on the south and Jalan Bota Kiri on the north. (Fig 4).

Visual and physical data/observation. The primary data is collected using EOS Canon DSLR cameras and technical sketches. Through the photo, every angle has been 
taken into consideration including the front, rear, staircase view, the left side, the right side, the door, the window and the interior.

Verbal data. The collections of verbal data are involved with questionnaire and semi-structured interviews. Through questionnaire, this research gathered all about demographics including owners' and current occupants' name, the origin of construction, house orientation and the history of the house. The interview involved semi-structured interview schedule to obtain the history and background of the house, important events occur in related to the house and family members.

\section{Data Analysis}

The area of study was divided into 8 zones (Zone A to $\mathrm{H}$ ), where each zone had 6 houses. The data analysis method used to explain the set of data that has been identified is through the schedule of frequency of a variation. 50 traditional Malay houses are acquired for data collection. The data obtained are through interviews with the residents.

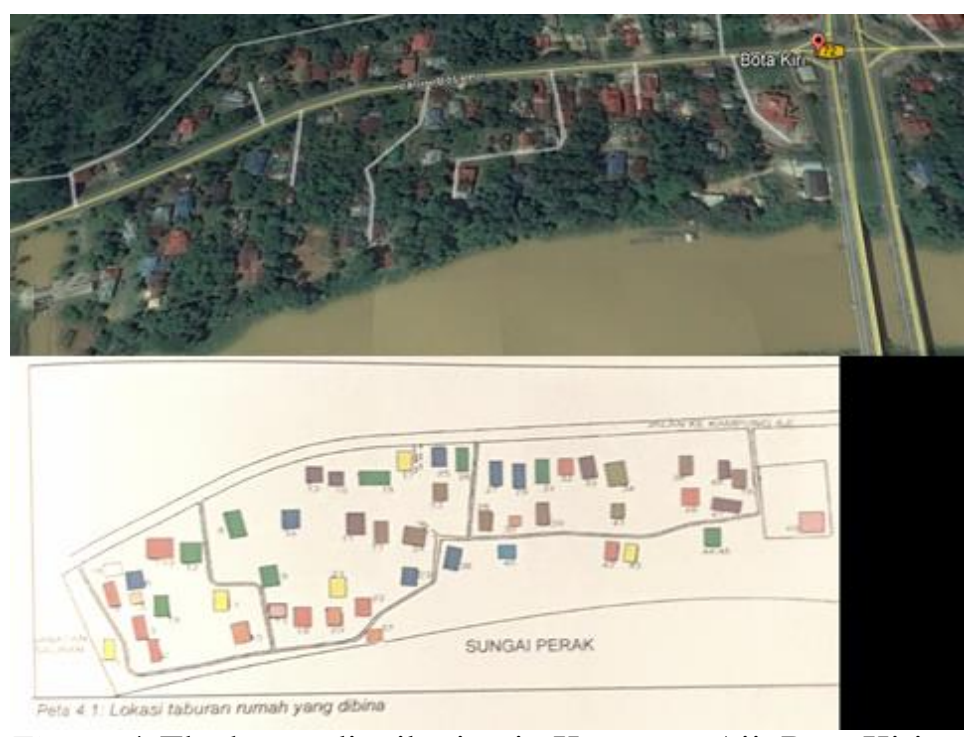

Figure 4. The house distribution in Kampung Aji, Bota Kiri

\section{Background of houses.}

Table 2 and Figure 5 show the number of houses built by year. The number of houses built around the 1970s was the highest number, of 9 houses followed by around 1920s of 8 houses. The abundance of construction around the 20's and 70's is believed to have been the result of major flood events that occurred in those years. In the 1900s only 3 houses were built in the study area and no construction was done around 1910 and around 1920 the construction was done so rapidly. However, construction has declined in subsequent years and rebounded in the 1970's. But around the 1980s, 1990s and 2000s there were not many houses built. 
Table 2: The Zone of Case Study

\begin{tabular}{|c|c|c|c|c|c|c|c|c|c|c|c|c|c|c|}
\hline Item & Zone & $\begin{array}{c}\text { House } \\
\text { Number }\end{array}$ & & & & & & t by $y$ & & & & & & \\
\hline & & & 1890 & 1900 & 1910 & 1920 & 1930 & 1940 & 1950 & 1960 & 1970 & 1980 & 1990 & 2000 \\
\hline 1 & A & 1 & & & & & & & $x$ & & & & & \\
\hline 2 & C & T1 & & $x$ & & & & & & & & & & \\
\hline 3 & A & 2 & & & & $x$ & & & & & & & & \\
\hline 5 & A & 3 & & & & $x$ & & & & & & & & \\
\hline 6 & A & 4 & & & & $x$ & & & & & & & & \\
\hline 7 & A & 5 & & & & & & & & & & & & $x$ \\
\hline 8 & A & 6 & & & & & $x$ & & & & & & & \\
\hline 9 & $\mathrm{H}$ & T6 & & & & & & & & $x$ & & & & \\
\hline 10 & D & T7 & & & & & & & & $x$ & & & & \\
\hline 11 & B & 8 & & & & & & & & & $x$ & & & \\
\hline 12 & B & T8 & & & & & & & & & $x$ & & & \\
\hline 13 & B & 9 & & & & & & & & & $x$ & & & \\
\hline 14 & B & 10 & & & & & & & & & & & $x$ & \\
\hline 15 & A & $\mathrm{T} 10$ & & & & $x$ & & & & & & & & \\
\hline 16 & B & 11 & & & & & & & $x$ & & & & & \\
\hline 17 & B & 12 & & & & & & & & & $x$ & & & \\
\hline 18 & C & 13 & & & & & & $x$ & & & & & & \\
\hline 19 & C & 14 & & & & & $x$ & & & & & & & \\
\hline 20 & C & 15 & & & & & & $x$ & & & & & & \\
\hline 21 & C & 16 & & $x$ & & & & & & & & & & \\
\hline 22 & C & 17 & & & & & & & & & $x$ & & & \\
\hline 23 & D & 19 & & & & $x$ & & & & & & & & \\
\hline 24 & D & 20 & & & & & & & & & & & $x$ & \\
\hline 25 & D & 21 & & & & & & & $x$ & & & & & \\
\hline 26 & D & 22 & & & & $x$ & & & & & & & & \\
\hline 27 & D & 23 & & & & & $x$ & & & & & & & \\
\hline 28 & D & 24 & & & & & & & & $x$ & & & & \\
\hline 29 & E & 25 & & & & & $x$ & & & & & & & \\
\hline 30 & $E$ & 26 & & & & & & & & & $x$ & & & \\
\hline 31 & $E$ & 27 & & & & & $x$ & & & & & & & \\
\hline 32 & $E$ & 28 & & & & & & & & $x$ & & & & \\
\hline 33 & E & 29 & & & & & $x$ & & & & & & & \\
\hline 34 & E & 30 & & & & & & & & & & & $x$ & \\
\hline 35 & $\mathrm{~F}$ & 31 & & & & & & & & & $x$ & & & \\
\hline 36 & $\mathrm{~F}$ & 32 & & & & $x$ & & & & & & & & \\
\hline 37 & $\mathrm{~F}$ & 33 & & & & & & $x$ & & & & & & \\
\hline 38 & $\mathrm{~F}$ & 34 & & & & & & & & & & $x$ & & \\
\hline 39 & $\mathrm{~F}$ & 36 & & & & & & & & $x$ & & & & \\
\hline 40 & $G$ & 37 & & & & & & & & & & & $x$ & \\
\hline 41 & $G$ & 38 & & & & & $x$ & & & & & & & \\
\hline 42 & $G$ & 39 & & & & & & & & & $x$ & & & \\
\hline 43 & G & 40 & & $x$ & & & & & & & & & & \\
\hline 44 & $G$ & 41 & & & & & & & & & & $x$ & & \\
\hline 45 & $\mathrm{H}$ & 42 & & & & $x$ & & & & & & & & \\
\hline 46 & $G$ & 43 & & & & & & & $x$ & & & & & \\
\hline 47 & $\mathrm{H}$ & 45 & & & & & & & & & $x$ & & & \\
\hline 48 & $\mathrm{H}$ & 46 & & & & $x$ & & & & & & & & \\
\hline 49 & $\mathrm{H}$ & 47 & & & & & & $x$ & & & & & & \\
\hline \multirow[t]{2}{*}{50} & $\mathrm{H}$ & 48 & & & & & & $x$ & & & & & & \\
\hline & & Total & & 3 & & 9 & 7 & 5 & 4 & 5 & 9 & 2 & 4 & 1 \\
\hline
\end{tabular}




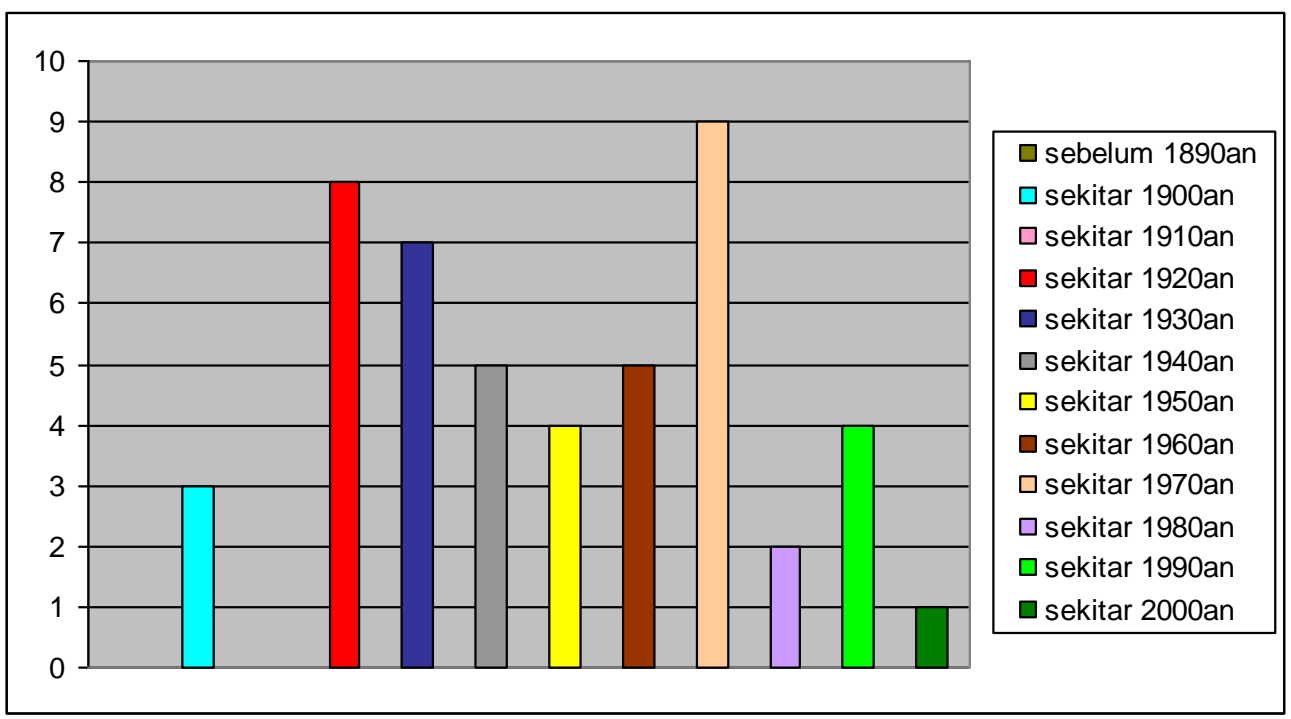

Figure 3: The chart of number of house built by year in Kampung Aji, Bota Kiri

\section{Findings}

The evolution of architectural language found from this study will be reviewed from two aspects which are:

1. The evolution of the exterior design concept

2. The evolution of the spatial planning

The evolution of the exterior design concept. Generally, the architectural design language of Kampung Aji can be divided into three style:
1.RK (Kutai house)
- before 20th century
2.RLBP (Limas house)
- early 20th century to 1960 's
3.RM (Modern house)
- 1960's to present

The RK is the oldest architectural style that still exists along Sungai Perak. The study found that RK were built in before 20th century. In Kampung Aji, there are two RK still in exist which are: the house of Tok Sedera Bongsu (T1) and a house that has been wakaf (donated) by the host to be used as a mosque (No. $49 \mathrm{ZON} \mathrm{H}$ ) at the east of Kampung Aji. Tok Seindera Bongsu house is still in its original form in terms of orientation but has undergone a few changes especially in materials used. The study found that houses that were built in the early 20th century until 1960's are RLBP. RK became less popular and taken over by RLBP style. The study found that there are few versions of RLBP in Kampung Aji:

i. $\quad$ Rumah Limas Anjung Satu Tingkap Dua Tangga Kiri (A1T2L)

ii. Rumah Limas Anjung Satu Tingkap Dua Tangga Kanan (A1T2R)

iii. Rumah Limas Anjung Dua Tingkap Dua Tangga Kiri (A2T2L)

iv. Rumah Limas Anjung Dua Tingkap Dua Tangga Kanan (A2T2R)

v. Rumah Limas Anjung Dua Tingkap Tiga Tangga Kiri (A2T3L)

vi. $\quad$ Rumah Limas Anjung Dua Tingkap Tiga Tangga Kanan (A2T3R)

vii. Rumah Limas Serambi Tengah 
Note: A- anjung, $T$ - tangga, $L$ - left, $R$ - right

The study also found houses that were built after the 1960s to date comprise houses that use the "modern architecture" style. The style or concept of modern architecture in the context of this study is defined the traditional houses using timber with zinc roof, semi-brickwall with zinc and fully brickwall with zinc and tile roofs.

The evolution of the spatial planning. In general, the allocation of space in the Malay house architecture in Kampung Aji has undergone a significant change process. The findings show that spatial planning has undergone three major changes.

RK is related to the change of the rumah ibu only. Rumah ibu in the RK has a same level of ruang serambi, kitchen area and bedroom. All family-related activities take place in rumah ibu. In the daytime, men spend their time outdoors either in the padi fields or in the farms. During night time everyone will be in their own bedrooms.

$R L B P$ undergoes changes in almost all space including rumah ibu, rumah selang (middle house) and kitchen house. Rumah ibu spaces has been categorized into ruang serambi, anjung, ruang tengah and kitchen. The male guest will enter through the front door which is located in the ruang serambi and directly onto anjung. Entertaining guests' activities such as kenduri and tahlil will be conducted in anjung area. If the number of guests were increased, the guests will spread to the middle room of rumah $i b u$. While the change for the middle house involves connecting space between rumah $i b u$ and the kitchen area. There is a steps at the rumah selang which is the gateway to the female guests. When a female guest feast will be served at the middle house and as the male guest is served in anjung house. The kitchen area is located at the back of RLBP and functioning as cooking area. An extra space in rumah limas is a bathroom space. The reason for added bathroom space inside the RLBP is it can reduce the occupants' movement to the well for the purpose of bathing and washing.

Finally, the evolutionary process also shows that most traditional Malay houses have changed their orientation position. The houses built at the end of the 19th century and in the early 20th century faces to the river. This is because during that era, the river is a medium for transportation and other economic activities. Starting in 1950, most home orientation is towards the road because the roads are the medium of transport and the people's economy.

\section{Conclusion}

Most home studios have been over 60 years old for almost a year. The physical condition of the house has been extinct and there are some houses that have collapsed or damaged. This study concluded that most of the owners of the traditional Malay house are among the tenants or their relatives. Some of the house also are uninhabited and abandoned because too old and not save to occupied. However, this study has succeeded in producing a result of studies showing changes in traditional Malay houses especially in Kampung Aji, Bota Kiri, Perak.

\section{Acknowledgement}


I would like to acknowledge and extend heartfelt gratitude to The Ministry of Higher Education and Universiti Teknologi MARA (UiTM) for funding this study under the Fundamental Research Grant Scheme (FRGS). My sincere thanks to all KUTAI members for their support and provided valuable comments of this article.

\section{References}

Andaya, B. W., (1979), Perak, the Abode of Grace. A Study of an Eighteenth- Century Malay State. Kuala Lumpur: Oxford U. Press.

Anuar Talib., (2006). The Perak Kutai Asli Malay House: Form, Function and Meaning Unpublished PhD Thesis, UiTM, Shah Alam, Selangor, Malaysia.

Ezrin Arbi, Ke Arah Jatidiri Senibina Dalam Konteks Nusantara, working paper presented at Simposium Nusantara, UiTM Cawangan Perak, Kampus Seri Iskandar. 21 Jun 1997.

Halim Nasir \& Wan Hashim Wan Teh (1996), The Traditional Malay House, Penerbit Fajar Bakti : Kuala Lumpur.

Lovichakorntikul, P. \& Walsh, J. (2011). Effective Channels for Establishing an Irlen Centre to Help People with Reading Problems in Thailand. Information Management and Business Review, 2(3), 99-105.

Mohd Sabrizaa Abd Rashid(2018), Rumah Kutai : Documentation of Memories, Institut Darul Ridzuan : Ipoh.

Mohd Sabrizaa Abd Rashid \& Sufian Che Ama t(2013), The Traditional Malay Architecture: Between Aesthetics and Symbolism in Mark Taylor (ed.), Interior Design and Architecture : Critical and Primary Sources, Vol 1.Bloomsbury Publishing : London.M.A Fawzi Basri (1986),

Mohd. Sabrizaa, A.R. et. al., Architectural Design Study of Kampung Aji, Bota Kiri, Institute of Research, Design and Consultancy (IRDC), UiTM. Mei 2005.

Norhasandi Mat et al., The Architecture of Perak Traditional Malay Roof Houses (PTMRH) in the Year of 1820-1940: A Chronological Analysis of the Arabesque Types on Wall of Rumah Ibu, Prosiding Simposium Nusantara 9 (SIMPORA 9:2012), Dewan AlKhawarizmi, UiTM Perak. 11 \& 12 Disember 2012.

Saleh, Y., Hashim, M., Mahat, H., \& Nayan, N. (2018). The Traditional Malay Houses in the District of Muallim, Perak: A Lost Legacy. International Journal of Academic Research in Business and Social Sciences, 8(2), 698-712.

Shireen Jahnet. et.al, (2017). The Resilience of Tradition: Malay Allusions in Contemporary Ar-chitecture. (S. J. Kashim, Ed.). Penang: Areca Books: Penang 